\title{
U.PORTO
}

EED FACULDADE DE ECONOMIA

UNIVERSIDADE DO PORTO

\section{The management of working capital and profitability of SMEs in the euro area}

\author{
by \\ Valentina Maria Sousa Cerqueira Lima
}

Masters Dissertation in Finance and Taxation

Supervisor: Prof. Doutor Francisco Vitorino da Silva Martins

Co-supervisor: Prof. Doutor Elísio Fernando Moreira Brandão 


\section{Brief Biographical Note}

Valentina Maria Sousa Cerqueira Lima was born in Ponte de Lima on 12 October 1992.

She completed her degree in Economics at the University of Minho in 2013.

While studying, she was involved in a number of external activities, including voluntary work at the Banco Alimentar contra a Fome food bank.

In the 2013/2014 academic year, she began a Masters in Finance and Taxation at the Faculty of Economics of University of Porto, culminating in the submission of this dissertation.

In July 2014 she began an internship at a SME, as assistant to the director of the financial area, with a total duration of 12 months.

In September 2015 she joined the Assurance department at Ernst \& Young. 


\section{Acknowledgements}

My sincere thanks to Prof. Francisco Vitorino da Silva Martins for his exemplary supervision of the research that led to this thesis. It would not have been possible without his time, support and encouragement.

My thanks also to my co-supervisor Prof. Elisio Brandão, director of the Masters in Finance and Taxation, for his support and encouragement to compete this thesis.

I would like to thank António Silva from Bureau van Dijk for his assistance in obtaining the data essential to be able to use the corporate governance variable in this study.

Special thanks to my family for always encouraging me to tackle challenges and to do more and better and for always being there.

Last, but not least, I would like to thank all my colleagues and friends for their company over this last year, particularly for all the great moments that gave me strength to overcome some of the obstacles that I faced.

Thanks to you all! 


\begin{abstract}
Short-term financial management involves the management of current assets and liabilities, which directly affect an organisation's liquidity and profitability. This study aims to examine the relationship between the operating performance and short-term financial management of small and medium-sized enterprises in Europe. Return on assets is used as a proxy for profitability and the cash conversion cycle is used as a proxy for working capital management. The analysis in this study is based on non-financial firms in 19 euro area countries, over a six-year period from 2008 to 2013. The negative and significant relationship between profitability and each of its determinants, such as average collection period, average payment period, average inventory period, cash conversion cycle and profitability, was found using the GLS and OLS methods. This means that managers may create value for shareholders through shorter collection periods, a guarantee of fast moving inventories and longer payment periods (provided this does not affect their credit risk). In addition, the governance structure of a firm affects how it reacts to external factors and influences its financial performance, for which reason the number of directors variable was included in this study in order to test this relationship. The results indicate that there is an inverse relationship between the number of director and profitability, which can be explained by the fact that a larger board of directors generates communication and decision problems. The positive relationship found between liquidity and profitability can be explained by the fact that firms use first of all the amount generated and accumulated internally before seeking external resources, especially in the case of SMEs, which have difficulties in obtaining external financing.
\end{abstract}

Key Words: Inventories, receivables, payables, cash conversion cycle, number of directors, SME. 


\section{List of Contents}

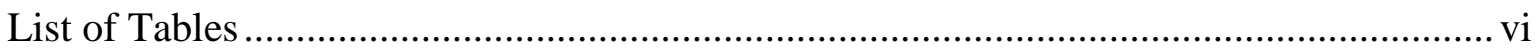

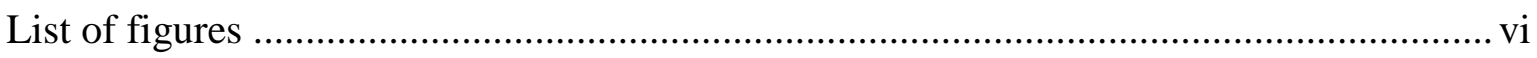

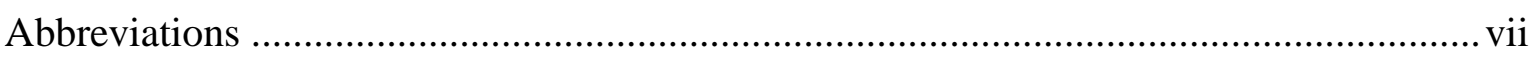

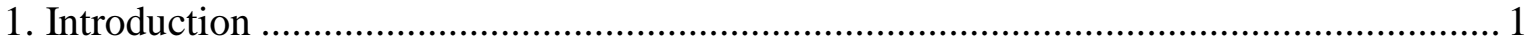

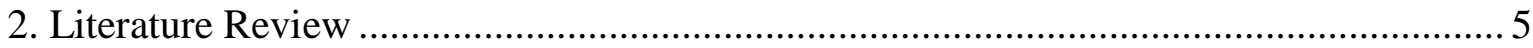

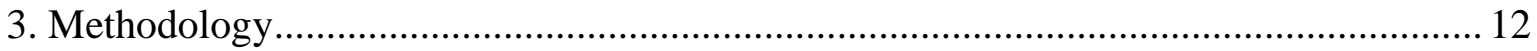

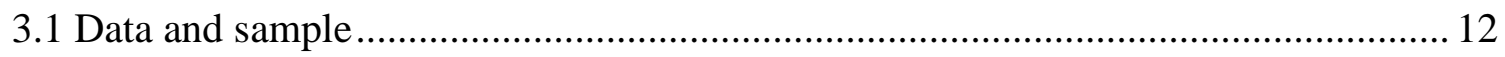

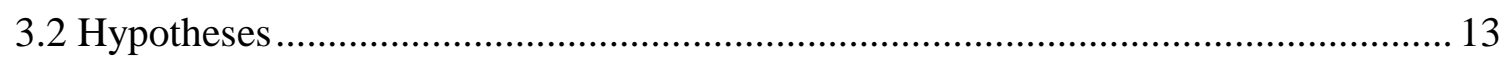

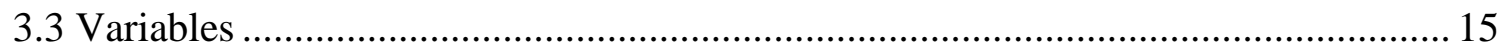

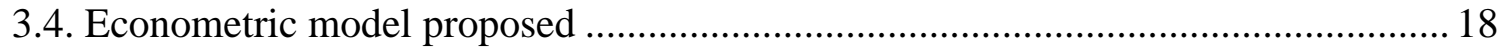

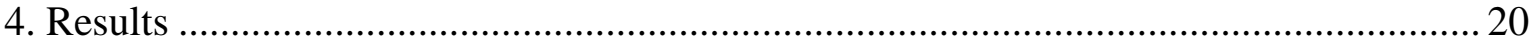

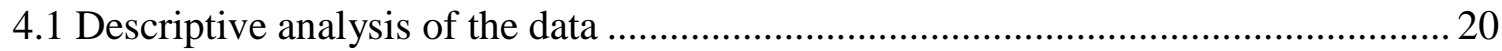

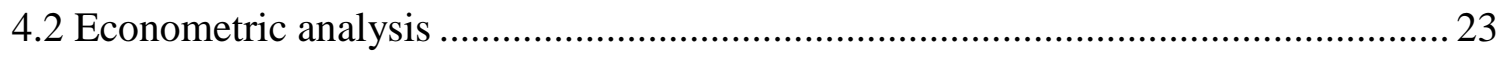

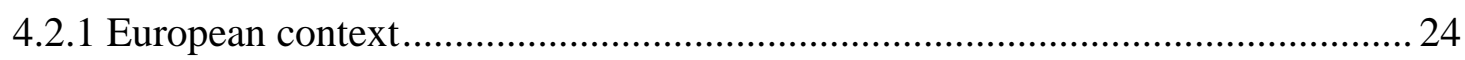

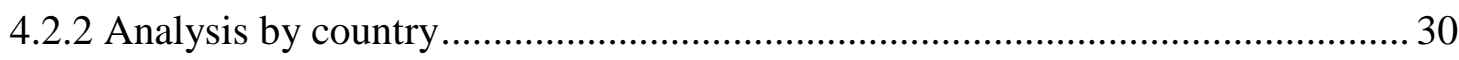

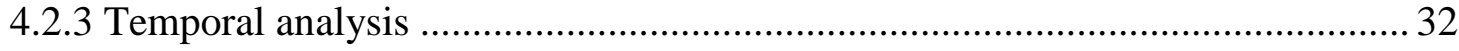

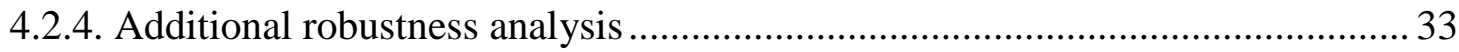

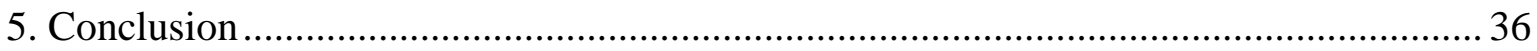

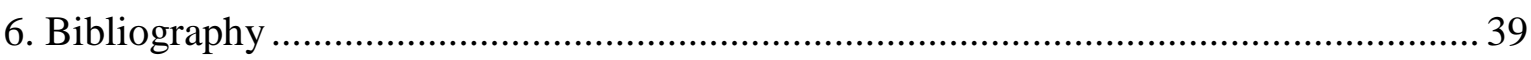




\section{List of Tables}

Table 1 - Formulas and abbreviations for variables ................................... 16

Table 2 - Average ROA, PMP, PRM, INV and CCC per sector ......................20

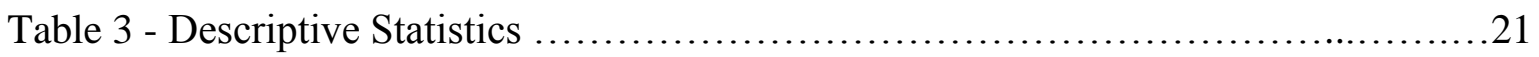

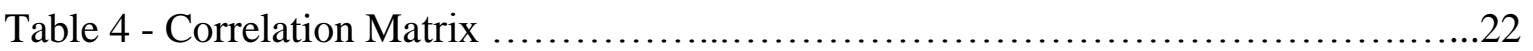

Table 5 - Working capital management and profitability (2008 to 2013) with GLS cross section weights and pooled OLS estimation methods ...............................25

Table 6 - Working capital management and profitability (2008 to 2013): regression with

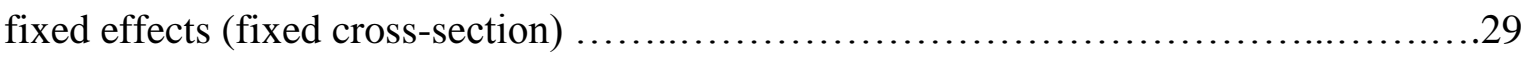

Table 7 - Analysis per country - Working capital management and profitability per country (2008 to 2013): GLS with cross-section weights .................................. 31

Table 8 - Temporal analysis - Working capital management and profitability (2008 to

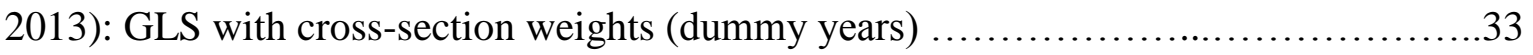

Table 9 - Robustness test - Working capital management and profitability (2008 to 2013): GLS with cross-section weights with alternative dependent variable .34

\section{List of figures}

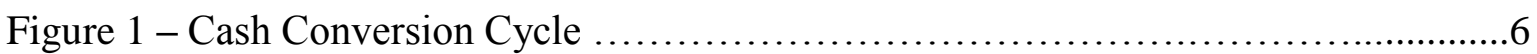




\section{Abbreviations}

ACP - Average Collection Period

APP - Average Payment Period

Board - Number of directors

CCC - Cash Conversion Cycle

CLR - Current liquidity ratio

DTI - Debt to income ratio

EU - European Union

GDP - Gross Domestic Product

GDPGR - Annual growth rate of GDP

GLS - Generalised least squares method

INV - Average inventory period

Log (TA) - Firm size

OLS - Ordinary least squares method

ROA - Return on assets

ROE - Return on equity

SGR - Sales growth

SME - Small and medium-sized enterprises

WC - Working Capital

WCR - Working capital requirement 


\section{INTRODUCTION}

Financial literature traditionally tends to focus its analysis on long-term financial decisions, including capital structure, investments, dividends and the assessment of firms. However, short-term decisions include analysis of management of the working capital, which involves important financial decisions with a direct impact on liquidity and profitability.

Most firms invest significant amounts in their working capital (Deloof 2003), in order to avoid defaulting on debts and short-term liabilities and thus avoid going out of business. Management of working capital is quite important because of its impact on profitability, on risk and consequently on the value of firms (Smith 1980). Its efficient management is essential for the survival and operability of organisations and is one of the most important decisions that managers have to take in day-to-day business. Low working capital restricts a firm's operating capacity and sales. However, high working capital may divert financial resources that could be applied in the firm's non-current assets. To this end, ensuring the correct amount of working capital is crucial to maximise profitability.

There is an optimum level of working capital that maximises the value of firms (Deloof 2003). These decisions are all the more important in the case of small and medium-sized enterprises (SME), because they normally have greater difficulty in accessing external financing markets than publicly-traded firms (García-Teruel and Martínez-Solano 2007). Moreover, the investment made by those firms also tends to focus above all on current assets and this management involves decisions about the amount, composition and financing of these assets. Current assets include all assets that, in the normal course of the firm's business, are easily transformed into cash within a short period of time, in general within one year, so that this temporary investment can be easily converted into cash when necessary (Raheman and Nasr 2007). Indeed, in the sample used in this study, the current assets of the SMEs represent $54 \%$ of their total assets.

Working capital management is a complex area of financial management. For this reason, effective management of the working capital tends to prevent excessive investment in current assets and also prevent defaulting on obligations. Apart from the fact that the ultimate aim of a firm is to maximise profits. However, liquidity is also a constant concern, 
particularly among SMEs (Shin and Soenen 1998, Raheman and Nasr 2007). In other words, some decisions that tend to maximise profitability tend to minimise an ideal level of liquidity (Shin and Soenen 1998, Deloof 2003, Wang 2002).

An analysis of SMEs is of significant importance given their role in the economy. SMEs play a key role in the development of the world economy as sources of innovation, employment and economic growth and are ultimately considered the backbone of a country's economy. In the European Union (EU) of 28 members, in 2013, there were more than 21.2 million SMEs in the non-financial business sector, representing $99.8 \%$ of private-sector firms in the EU28, 66.8\% of total employment and $57.9 \%$ of value creation generated by the non-financial sector. Thus, appropriate working capital management is especially important for SMEs (Pell and Wilson 1996), since they represent a large share of economic activity.

The central aim of this research is to examine the joint efficiency of management measures for working capital and corporate governance for a set of small and medium-sized enterprises in the euro area. Unlike other studies, an additional variable is introduced (number of directors) as a proxy for corporate governance. Earlier studies have focused above all on analysis of larger firms for a particular context. This research will contribute to the aforementioned relationship at a board level - by using a set of SMEs. It will also help owners/managers, governments, consultants and financial institutions to opt for better policies and decisions with regard to European SMEs. The analysis in this study is based on non-financial firms in 19 European countries, over a six-year period from 2008 to 2013. The regression used in this study was GLS and OLS. The results were robust and it was concluded that working capital management unequivocally affects profitability in European countries.

This dissertation analyses the impact of management of the different components of working capital on the profitability of firms and how these components occur. It also takes into account the corporate governance component that can influence how working capital is managed and hence profitability.

Inefficient management of working capital, caused by bad management, can have a negative impact on the wealth of shareholders. High inventory levels and a generous 
customer credit policy can boost sales. Higher inventory levels also reduce stockout risk. However, a longer collection period may encourage sales, since it allows consumers to have access to goods before paying for them. Delaying payments to suppliers can be a cheaper and more flexible way of having access to financing. But it may mean a loss of access to early payment discounts. It may also mean that the firm is finding it difficult to fulfil its obligations. The most popular measure for working capital management is the cash conversion cycle (CCC). The $\mathrm{CCC}$ represents the period of time between the acquisition of raw materials and the receipts from sales of finished products. According to Deloof (2003), the longer this time span, the greater the investment in capital. A longer CCC may lead to an increase in profitability by boosting sales. Nevertheless, profitability may also fall with the CCC if the costs of greater investment in capital increase faster than the benefits of holding more inventory and/or improving the credit policy. Poor management of receivables, payables and inventories may have a negative impact on the CCC.

Besides effective short-term management, other issues that firms need to consider concern corporate governance (CG). This is because inefficient short-term management and poor CG may have a negative impact on profitability and on the value of a firm (Gill and Biger 2013), which may jeopardise growth and operational implementation.

Corporate governance is the process and structure used to direct and manage business with the aim of increasing shareholder value, taking into account the interests of all the stakeholders. For SMEs, corporate governance covers the interests of shareholders, as well as owners, managers or directors (Abor and Biekpe 2007). And although earlier studies of corporate governance performance and characteristics have been associated above all with larger firms, because of the separation between owners and managers, best management practices help SMEs to improve their efforts to guarantee financing by investors and financial institutions.

Miringu and Muoria (2011) note that the governance structure of any firm affects how it reacts to external factors and influences its financial performance. Consequently, best management practices are associated with better performances, which are in turn reflected in an increase in value for shareholders. Achchuthan and Kajananthan (2013) argue that 
corporate governance measures are strategies formulated to meet short, medium and long term organisational targets, as well as the objectives of shareholders. Consequently, effective management of the WC is an important mechanism for fulfilling short-term ambitions. This is because although working capital components include the credit policy, inventory policy and payment policy, cash on hand to cover short-term liabilities is quite vulnerable to the conduct of managers (Isshaq et al. 2009). Managers may have a direct influence on the management of the WC, since they are normally responsible for the policies related to cash management, receivables and payables and inventory, etc. The strategic decisions to be implemented by the number of directors/managers play an important role, as they may lead to larger volumes of receivables or cash balances or to a rapid cash cycle. The board of directors thus plays an important role in organisations since its directors may encourage cash balances, increase the volume of receivables, increase payables or decrease the CCC (Gill and Biger 2013). Poor management may have serious consequences for the management of liquidity, receivables, payables, inventories and CCC.

The presentation of the next sections of this work is as follows. The next section is a literature review. Section three describes the methodology, data, hypotheses and variables under investigation. Section four presents the empirical results. Finally, the last section corresponds to discussion and presentation of the conclusions of this study. 


\section{LITERATURE REVIEW}

There have been several empirical and theoretical studies of the effect of working capital management on profitability, considering different periods, countries and sectors. In literature, the interaction between the cash conversion cycle and profitability has traditionally suggested that a longer cycle tends to decrease profitability. Many studies have demonstrated that it is possible to improve profitability by reducing the cash conversion cycle, because they have found a negative relationship between the two variables. When the different components of the cash conversion cycle are analysed, their effects on profitability tend to vary according to the study in question. It has been seen that effective working capital management prevents a firm, even if it is profitable, from being required to shut down, due to an incapacity to satisfy debts and short-term liabilities (Richards and Laughlin 1980).

Normally, in an analysis of short-term financial balance, working capital tends to focus on components that are only connected to the operating cycle, such as stock inventories, credit granted to customers, credit granted by suppliers, advances from customers, advances to suppliers and other operating debits or credits (Neves 2012).

Working capital requirements (WCR) reveal the borrowing requirements of the operating cycle, in which a firm must ensure a certain value for operating expenses before collecting from customers. However, WCR vary depending on the sector of activity and even within the same sector they may vary from one firm to another. For example, in the construction industry, WCR are very high compared to sectors with lower storage requirements and shorter economic cycles. Within the same sector, these WCR may vary according to each firm's level of technological progress and management.

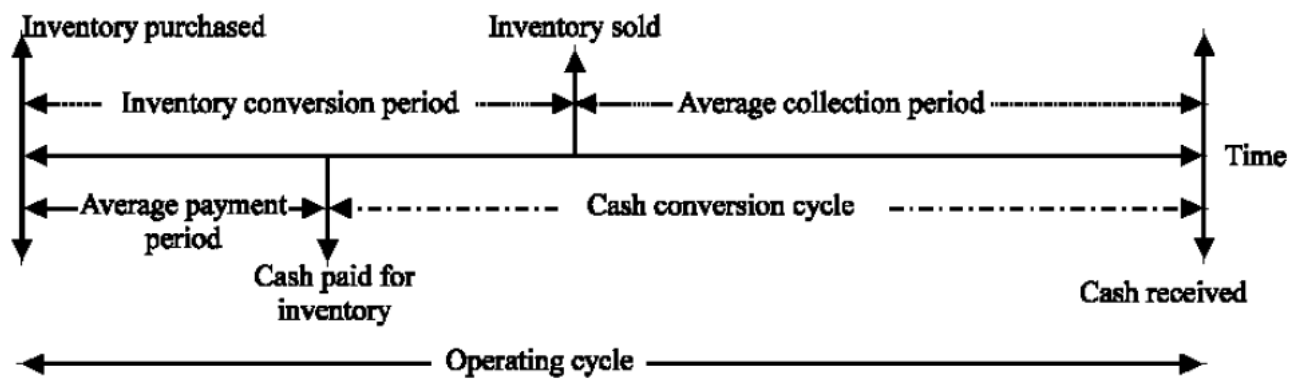

Figure 1: Cash conversion cycle. Source: Ross et al.(2003) 
The amounts that firms need to finance operating expenses and thus address the time lag between the acquisition of raw materials and the receipts from customers corresponds to the WCR.

Financial management aims to determine at all times the optimum investment in WC, in other words, the layer of investment that corresponds to the WCR. However, as a general rule, there are many elements that influence this optimum level of current assets and liabilities. In the literature, there are main two approaches to how working capital is managed, either through conservative policies or through aggressive policies. Aggressive policies are characterised by small proportions of current assets, with low levels of cash balances, low levels of inventories and short customer credit periods. This situation represents a high risk level with regard to payment of short-term debts (Van-Horne and Wachowicz 2004). From the perspective of conservative policies, the level of investment in current assets is high, with larger cash balances, inventories and better credit policies. However, the way this type of policy is managed entails considerable risks for the profitability of firms. Strategies based on more conservative policies tend to boost sales due by extending trade credit periods (Petersen and Rajan 1997).

Considerable inventory levels reduce the risk of stockout and a consequent loss of customers. However, high inventories imply greater mobilisation of working capital to this balance sheet item, to the detriment, for example, of the investment of these amounts in potential investment project with strong likelihood of growth.

Most SMEs see payment periods as strong and viable opportunities for external financing, due to the fact that they often encounter constraints on financing from financial institutions. However, this type of financing can imply a loss of early payment discounts, which may have contributed to an increase in profitability if they had been obtained.

The percentage of current assets in relation to non-current assets is quite high in the case of SMEs, since they tend to have mostly short-term assets (García-Teruel and MartínezSolano 2007). According to this principle, WC management is crucial for the survival and continuity of operations of an SME. 
One of the problems that SMEs face is that managers often focus exclusively on sales growth, which carries a high risk of granting credit to customers that are unable to pay. In addition, according to Atrill (2009), SMEs often do not have an effective collection department. This leads to an increase in the risk of overdue receivables. Atrill (2009) also mentions another problem faced by SMEs, based on their lack of market power; for example when a potential customer exceeds the credit limit, payment pressure may affect future negotiations.

Optimum management of working capital implies effective and efficient supervision and administration of WC management, which, according to financial literature, involves data related to average collection periods (ACP), average payment periods (APP), inventory conversion periods (INV) and cash conversion cycles (CCC), as set out in figure 1.

The ACP corresponds to the time interval during which sales are converted into cash. The APP corresponds to the time interval in which the firm has to pay its suppliers. The INV corresponds to the time between the entry of raw materials and the exit of end products. The CCC represents the time interval between the payment of raw materials and receipt of cash from sales. In other words, the CCC is eventually defined as part of the operating cycle that is financed by the firm itself (McLaney 2006). According to Baños-Caballero $(2010 ; 2012)$ the aim is to achieve an optimum level of each of these components. The synchronisation of these flows is essential to guarantee a firm's liquidity, since decisions about how much should be invested in inventories and in the management of customer accounts and about credit levels accepted by suppliers, are reflected in a firm's cash cycle.

The device most commonly used to empirically measure short-term financial management has been CCC, as in studies by Shin and Soenen (1998), Deloof (2003), Lazaridis and Tryfonidis (2006); García-Teruel and Martínez-Solano (2007) and Baños-Caballero et al. (2012). In general, the results of these studies show that better management of the CCC has a positive effect on the firm's profitability, although this impact is mainly driven by better credit and inventory policies, while accounts payable tend to be neglected (Knauer and Wöhrmann 2013).

In contrast, Karadagli (2012), who used operating income as a measure of profitability, noted that in the particular case of the SMEs in his sample, profitability increased with the 
increase in CCC. A similar result was found in the study by Amarjit et al.(2010), who used EBITDA as an indicator of profitability, for American firms.

In a more recent study, of 1008 Spanish firms, for the period from 2002 to 2007, BañosCaballero et al. (2012) found evidence of a concave relationship between profitability and working capital. This means that better working capital management can only increase profitability up to a certain level. In other words, it shows that there is an optimum point for WC that maximises profitability.

Deloof (2003) analysed a sample of large Belgian firm for the period from 1992 to 1996 and the results confirmed that firms can improve their profitability through an increase in their CCC. He also reported on the existence of an inverse relationship between profitability and average collection periods, average inventory periods and average payment periods. These results show that firms with greater difficulties tend to delay their payments. Raheman and Nasr (2007) also studied the effect of the different constituents of working capital, but for Pakistani firms, and also concluded, like Deloof (2003), that there is an adverse relationship between the aforementioned components and profitability. In addition, they noted that there is a trade-off between liquidity and profitability. Lazaridis and Tryfonidis (2006) used a sample of 131 firms listed on the Athens Stock Exchange from 2001 to 2004, in which they noted that the relationship between profitability, measured by gross operating profit and CCC was statistically significant. Like Deloof (2003), they concluded that less profitable firms tend to delay payments.

García-Teruel and Martínez-Solano (2007) made an empirical analysis of the impact of working capital on the profitability of Spanish small and medium-sized enterprises, for the period from 1996 to 2002. Like the previous authors referred to above, they found a negative relationship between profitability and average collection time and between profitability and the levels of inventory turnover. However, they did not find a statistically significant relationship between firms' average payment time and profitability, since this relationship loses significance when problems of endogeneity are controlled. They concluded that managers can increase value by reducing stocks and the average payment time extended to customers. In addition, they noted that a smaller CCC was associated with 
more profitable firms, which in turn presented a higher sales growth rate, larger size and lower leverage.

Likewise, Deloof (2003), Lazaridis and Tryfonidis (2006) and García-Teruel and MartínezSolano (2007) stress that managers are able to create value for shareholders by reducing the ACP and INV to a reasonable minimum.

The size of a firm is one of the factors that influences investment in working capital. In the case of SMEs, this issue is of particular importance, due to the fact that many of these firms have above all current assets and a majority encounter difficulties in obtaining financing (García-Teruel and Martínez-Solano 2007). There is evidence that firms of a smaller size tend to rely on financing through suppliers, which in turn reduces their CCC (Baños-Caballero et al. 2010). Furthermore, they tend to optimise an optimum period of the CCC, since small firms, such as SMEs, are subject to greater information asymmetries and a greater likelihood of insolvency/bankruptcy. On the other hand, a study by Abbadi and Abbadi (2013) mentions that larger firms are attributed greater negotiation power, which in turn increases the probability of better financing conditions with their suppliers, and improves credit conditions.

To respond to higher or lower demand or to take advantage of possible opportunities for growth, a manager tends to take decisions with a direct impact on working capital management, mainly through the credit levels made available to customers and through levels of stocks. For this reason, other factors, such as the board of directors or supervisory board, may also determine firms' options with regard to the amount to be invested in working capital.

As a result of business and market failures, the question of corporate governance has received considerable attention, with regard to firms' internal decision and supervisory structures. Appropriate and effective CG practices have been important, not only to improve financial performance but also to attract capital investment (Velnampy and Pratheepkanth 2013). For a fair and balanced presentation of the firm's position, no individual should have unlimited power of decision and a board of directors should have a good balance of knowledge and experience (Ukaegbu 2014). In this article, Ukaegbu considered, in addition to the traditional components of working capital, that the size of the 
board of directors could influence short-term management and hence a firm's profitability , in different African countries, with different industrial levels. He found a positive relationship between profitability and firm size, arguing that larger firms can attract more competent managers, have access to better technology and make use of economies of scale. However, he also noted a negative relationship between the size of the board of directors and profitability. This implies that a larger board can be characterised by inefficiency. Although there is no ideal size for a board of directors, Lipton and Lorsch (1992) argue that the ideal would be 8 to 9 directors, while Jensen (1993) claims that the ideal would be around 7 to 8 directors. Furthermore, the relationship between the size and performance of the board of directors may vary not only with the specific characteristics of firms, but also with the specific institutional characteristics of each country, since countries with different characteristics may assign different duties to the board of directors.

Abor and Biekpe (2007) concluded that a larger board of directors improves the performance of firms, due to greater diversity and variety in the sharing of experience. Mollah, Farooque and Karim (2012) also concluded that a larger board is associated with better performance. Jensen (1993), on the other hand, argued that a smaller board tends to be more effective in supervision, control and decision-making by firms.

Gill and Biger (2013) conducted a study of industrial firms in the USA from 2009 to 2011. Average collection period, average payment period, CCC, current ratio and sales growth were the variables used to measure the efficiency of the working capital. They concluded that the size of a firm improves the efficiency of management of accounts payable, which in turn helps to reduce capital requirements. However, the size of the board of directors does not improve the CCC. So for American industrial firms a larger board of directors did not improve the efficiency of management by the board of directors. Nevertheless, in general they concluded that CG best practices improve management efficiency in the short term. Kajananthan and Achchuthan (2013) did not find a significant relationship between corporate governance and effective WC management.

In conclusion, earlier studies have mostly analysed the impact of management of current assets and liabilities on profitability. Nevertheless, some studies introduce corporate governance variables that indicate that $\mathrm{CG}$ best practices tend to improve working capital 
management and consequently performance. This study aims to explore the relationship between short-term financial management and its effects on profitability, taking into consideration a CG variable, but for a set of different European countries and sectors of activity and considering only SMEs. 


\section{METHODOLOGY}

This section will present the data and hypotheses underlying this study, as well as the variables and their specifications for the model used. The most widely used indicator is return on assets (ROA). With regard to the explanatory variables, the efficiency of working capital management is measured using the cash conversion cycle and its components: average collection period, average payment period and average inventory period.

\subsection{Data and sample}

The data used in this study were obtained from the Amadeus database, which contains financial and economic information on European firms. In addition, to introduce the effects of economic cycles on levels of investment in working capital, information on the growth rate of the gross domestic product (GDP) of each country was obtained from Eurostat.

The sample consists of small and medium-sized enterprises from the 19 euro area countries listed below: Cyprus, Estonia, Belgium, Austria, Portugal, Spain, Italy, Netherlands, Lithuania, Luxembourg, Malta, Finland, France, Germany, Greece, Ireland, Slovakia, Slovenia and Latvia.

The selection of the SMEs was made in accordance with the criteria set out in Article 2 of the annex to Commission Recommendation 2003/361/EC ${ }^{1}$ :

"1. The category of micro, small and medium-sized enterprises (SMEs) is made up of enterprises which employ fewer than 250 persons and which have an annual turnover not exceeding EUR 50 million, and/or an annual balance sheet total not exceeding EUR 43 million.

2. Within the SME category, a small enterprise is defined as an enterprise which employs fewer than 50 persons and whose annual turnover and/or annual balance sheet total does not exceed EUR 10 million.

3. Within the SME category, a microenterprise is defined as an enterprise which employs fewer than 10 persons and whose annual turnover and/or annual balance sheet total does not exceed EUR 2 million.”

\footnotetext{
${ }^{1}$ Commission Recommendation 2003/361/EC (2003, pp. L 124/36), Official Journal of the European Union
} 
During the economic crisis, the European Union has faced adverse financial conditions, however SMEs have maintained their position as mainstays of the European economy, with approximately 20 million enterprises that represent more than $99.8 \%$ of the total number.

Firms were selected from different economic sectors. Firms in the financial and insurance sector were excluded, because their financial characteristics and investment in working capital are substantially different from that of non-financial firms. In addition, a series of additional filters were applied. Observations concerning firms with anomalies in their accounts, such as negative or amounts null reported in their current assets, sales, purchases, cost of materials consumed and stocks were eliminated. Firms with a lack of data were also removed from the sample. Winsorising, to remove possible outliers, was conducting considering at the same time a minimum of 0 years and a maximum of 3 years for the variables average collection period, average inventory period and average collection period.

The amounts are in euros for all years and states.

After the application of the criteria presented above, a panel data were obtained for 49347 firms, resulting in a total of 219643 observations.

Observations from Austria represent $0.14 \%$ of the sample, from Belgium 9.11\%, from Estonia $1.51 \%$, from Finland 3.96\%, from Germany $2.41 \%$, from Italy $62.08 \%$, from Latvia $0.04 \%$, from Luxembourg 0.03\%, from Portugal 2.06\%, from Slovakia 7.19\%, from Slovenia $2.10 \%$ and from Spain $9.38 \%$.

\subsection{Hypotheses}

The aim of this research is to analyse the impact of short-term financial management measures, taking into account CG characteristics, on the profitability of a set of European SMEs.

One of the most crucial aspects of working capital management is the efficient management of each of its individual components: cash, receivables, payables and 
inventories. According to Baños-Caballero et al. (2010:2012), the aim of working capital management is to find an optimum level of each of these components, due to their impact on the risk and profitability of firms.

H1: There is an inverse relationship between the cash conversion cycle (CCC) and profitability of SMEs.

The traditional measure of efficiency of working capital management corresponds to the concept of $\mathrm{CCC}$, which corresponds to the time lag between payment for the acquisition of raw materials and receipts from the sales of finished products. By reducing this time lag, in other words, compliance with the CCC, profitability is increased (Shin and Soenen 1998, Lazaridis and Tryfonidis 2006).

H2: There is an inverse relationship between the average collection period and profitability of SMEs.

The profitability of a firm depends in part on how receivable are managed. According to García-Teruel and Martínez-Solano (2010), an efficient credit policy is necessary for a firm's survival, due to its effects on levels of investments in assets and its impact on value and profitability. Deloof (2003) notes that a good credit policy can attract customers, resulting in higher sales and hence increased profitability. However, although it may stimulate sales growth, extending more credit to customers is associated with various disadvantages. In particular, the increased risk of impairment of receivables, less funds available and higher WCR, which may lead to a need for external financing, leading to higher financing costs. For which reason shorter collection times stimulate an increase in profitability, since they imply larger cash holdings.

H3: There is an inverse relationship between the average payment period and profitability of SMEs.

In payables, if the firm delays payments to suppliers, this method may act as a source of financing, but, on the other hand, it may be quite disadvantageous, if the firm could have obtained discounts for early payments. There is still the fact that firms with greater difficulties take more time to pay their suppliers. If a firm delays its payments up to a certain point, it increases its profitability (Lazaridis and Tryfonidis 2006). In other words, 
the existence of this inverse relationship which means that with adequate planning, such as an estimated payment plan, it can afford firms advantages/discounts from their suppliers, which may significantly reduce the cost of their purchases and in turn increase profitability. This result makes economic sense to the extent that the more the firm delays payment to suppliers, the more capital it has available to increase profitability. However delays in payments may also indicate financial problems.

H4: There is an inverse relationship between the average inventory turnover and profitability of the SME

High inventories tend to encourage sales, minimise the risk of stockout and of price fluctuations (Deloof 2003). Normally managers/owners tend to balance an optimum level of risk and return (García-Teruel and Martínez-Solano 2007). However, the longer inventories are held, the greater the storage costs, the lower the turnover of goods, the greater the tying up of capital and the greater the likelihood of materials becoming obsolete.

H5: Corporate governance measures have an impact on working capital management.

Abor and Biekpe (2007) mention that a larger board is more efficient due to the diversity and variety of experiences. The number of directors is expected to increase with the need for information. This need is likely to increases with the size of the firm and its consequent complexity. In contrast, other studies, such as Jensen (1993), argue that a smaller board of directors is more efficient in supervision, control and decision-making, since a smaller board increases the personal responsibility of each member.

\subsection{Variables}

The variables selected in this study ere based on earlier empirical studies, especially Lazaridis and Tryfonidis (2006) and the data available.

Table 1, presented below, summarises all the variables used in this study, in addition to their abbreviations and formulas. 
Table 1 - Formulas and abbreviations for variables

\begin{tabular}{|c|c|c|}
\hline Variables & Abbreviation & Description \\
\hline Return on Assets & $\mathrm{ROA}$ & EBIT/ASSETS \\
\hline Average Collection Period & $\mathrm{ACP}$ & $($ receivables/sales) $* 365$ \\
\hline Average Payment Time & APP & (payables/COGS)*365 \\
\hline Average Inventory Period & INV & $($ stock/COGS)*365 \\
\hline Cash Conversion Cycle & $\mathrm{CCC}$ & $\mathrm{ACP}+\mathrm{INV}-\mathrm{APP}$ \\
\hline Debt to Income Ratio & DTI & $\begin{array}{l}\text { (short-term debt }+ \text { debt long- } \\
\text { term)/total assets }\end{array}$ \\
\hline Size & $\log (\mathrm{TA})$ & LN(assets) \\
\hline Current Liquidity Ratio & CLR & Current assets/current liabilities \\
\hline Sales Growth & SG & $\left(\right.$ Sales $_{n}-$ Sales $\left._{n-1}\right) /$ Sales $_{n-1}$ \\
\hline Macroeconomic Conditions & GDPGR & Real GDP Growth Rate \\
\hline Number of Directors & Board & Number of directors \\
\hline Sector of Activity & Sector & $\begin{array}{l}=1 \text { Industrial sector } ;=2 \text { Retail Trade; } \\
=3 \text { Wholesale Trade }=4 \text { Construction; } \\
=5 \text { Services } ;=6 \text { Transport }\end{array}$ \\
\hline
\end{tabular}

Return on assets (ROA) will be used as a measure of profitability. The dependent variable corresponds to ROA (García-Teruel and Martínez-Solano 2007 and Falope and Ajilore 2009), which quantifies the income provided to the firm by the investment in assets. This variable was defined as the ratio between income before interest and taxes on assets.

The independent variables related to working capital management correspond to the average collection period (ACP), average payment period (APP) and average inventory period (INV).

The average collection period (ACP) represents the average number of days the firm has to receive payments from its customers and is calculated using the following expression: (receivables/sales)*360. Receivables corresponds to the value of the trade receivables item. Trade receivables include consumers that have not yet paid for goods or services already provided by the firm. The aim of the manager of these debts is to minimise the collection time. 
The same category includes average payment period (APP), which reflects a given firm's payment policy, in other words it reflects the average time interval before the firm pays its suppliers. The APP is defined as the ratio (Payables/ cost of goods sold)*365. Payables includes the amounts owed to suppliers, in other words, it includes invoices already processed by suppliers, but yet not paid.

The average inventory period (INV) variable expresses the average number of days that stock remains at the firm. This variable is used as a proxy for the inventory policy and is calculated as follows: (inventory/cost of goods sold)*365. Inventory corresponds to the stock list of raw materials, plus work on intermediate or final goods that are waiting to be used for production or to be sold.

Working capital management is expressed through the CCC proxy. The CCC is calculated by adding the items average collection period and average inventory period, from which is subtracted the average payment period, in other words $\mathrm{CCC}=\mathrm{ACP}+\mathrm{INV}-\mathrm{APP}$. The $\mathrm{CCC}$ can be interpreted as the time interval between payment of raw materials and receipts from finished products. The greater the CCC value, the greater the time lag between payment of raw materials and receipts from finished products, which will be reflected in a higher value of the working capital.

The number of directors variable was used to measure board of directors size in order to associate working capital efficiency with management measures. A number of recent empirical studies (Boone et al. 2007; Coles et al. 2008 and Guest 2008) have examined the determinants of board of directors size. The size of the board is expected to increase with the need for information and the need for advice. This necessity is expected to increase with the complexity and size of firms.

Other variables that influence the profitability of firms and their performances were used as control variables, including size, debt to income ratio, current liquidity ratio and sales growth. Size is measured using the logarithm of assets. The literature suggests that there is a positive relationship with profitability, since larger firms tend to achieve higher levels of profitability compared to smaller firms (García-Teruel and Martínez-Solano 2007). 
The debt to income ratio is defined by the sum of short and long-term debts over total assets. The literature suggests a negative relationship with profitability, because an increase in a firm's levels of borrowing entails higher financing costs, which are in turn reflected in lower profitability (Deloof 2003, Lazaridis and Tryfonidis 2006 and Enqvist et al. 2014).

The current liquidity ratio corresponds to the ratio of current assets over current liabilities and is the traditional measure of liquidity.

For the sales growth variable, calculated as the current year's sales less the previous year's sales over the previous year's sales, the literature suggests that increased sales will result in increased profitability (Deloof 2003 and García-Teruel and Martínez-Solano 2007).

GDP growth reflects the macroeconomic conditions, in which there is expected to be a positive relationship, since firms' profitability is expected to increase in periods of economic expansion and vice-versa (García-Teruel and Martínez-Solano 2007, Enqvist et al. 2014).

\subsection{Econometric model proposed}

The methodology used is based on statistical inference, which is used to analyse the impact of CCC components on the profitability of a set of European SMEs. In this case, panel data were used, in which individuals, in other words firms, were observed at various points in time.

By using a panel data methodology, it was possible to analyse regression, taking into consideration both a spatial dimension (cross-section) and a temporal dimension (timeseries). There are significant advantages to this type of methodology, since it assumes that the firms are heterogeneous. Furthermore, panel data can be used to obtain a larger amount of data, including joint information on cross-section and time-series variables, greater variability, more degrees of freedom, greater efficiency and less collinearity between variables (Baltagi 2001). If the model fulfils all the classical regression assumptions, regression can be estimated using the ordinary least squares method (OLS). If the problem 
of heteroscedasticity is detected, it will be necessary to use the generalised least squares method (GLS).

To decide between a fixed or random effects model, a Hausman test (1978) is conducted, in which the null hypothesis is that the preferred model is random effects. If the null hypothesis is rejected, the model to be considered will be fixed effects. If the null hypothesis is accepted, then the random effects model will be preferred.

According to earlier studies, estimates of the effects of working capital management on the profitability of SMEs were obtained using the following regressions (García-Teruel and Martínez-Solano 2007 and Ukaegbu 2014):

$R O A_{i t}=\beta_{0}+\beta_{1} C C C_{i t}+\beta_{2} R E_{i t}+\beta_{3} \log (T A)_{i t}+\beta_{4} R L C_{i t}+\beta_{5}$ Board $_{i t}+\beta_{6} P_{I B g r}+\beta_{7} \operatorname{sgr}_{i t}+\varepsilon_{i t}$

$R O A_{i t}=\beta_{0}+\beta_{1} P M R_{i t}+\beta_{2} R E_{i t}+\beta_{3} \log (T A)_{i t}+\beta_{4} R L C_{i t}+\beta_{5}$ Board $_{i t}+\beta_{6} P I B g r_{i t}+\beta_{7} \operatorname{sgr}_{i t}+\varepsilon_{i t}$

$R O A_{i t}=\beta_{0}+\beta_{1} P M P_{i t}+\beta_{2} R E_{i t}+\beta_{3} \log (T A)_{i t}+\beta_{4} R L C_{i t}+\beta_{5}$ Board $_{i t}+\beta_{6} P I B g r_{i t}+\beta_{7} \operatorname{sgr}_{i t}+\varepsilon_{i t}$

$R O A_{i t}=\beta_{0}+\beta_{1} I N V_{i t}+\beta_{2} R E_{i t}+\beta_{3} \log (T A)_{i t}+\beta_{4} R L C_{i t}+\beta_{5}$ Board $_{i t}+\beta_{6} P I B g r_{i t}+\beta_{7} \operatorname{sgr}_{i t}+\varepsilon_{i t}$

In which I refers to the firms, $t$ represents the years and ${ }^{\mathcal{E}}$ the error term. The definition of the variables is described in Table 1.

The equations specified above were estimated using the generalised least squares (GLS) method given the heteroscedasticity (cross-sectional part of the sample) caused by the different firms present in this study and using pooled-OLS (ordinary least squares method) with dummy variables for sector, country and year. 


\section{RESULTS}

The results of this study will be presented throughout this section. A descriptive analysis will be presented first, followed by an analysis of the correlation matrix.

\subsection{Descriptive analysis of the data}

Depending on the sector of activity in which the firms operate, the composition of their current assets and liabilities vary substantially. Thus, Table 2 presents the operating profitability of assets and the number of days of receivables, inventories and payables by sector of activity. The wholesale trade sector presents a higher ROA at $5 \%$, followed by retail trade and the industrial sector with $4 \%$.

Table 2 - Average values, per sector

\begin{tabular}{lccccc}
\hline \multicolumn{1}{c}{ SECTOR } & ROA & ACP & INV & APP & CCC \\
\hline Industrial & 0.04 & 113.42 & 174.63 & 133.49 & 154.57 \\
Retail Trade & 0.04 & 52.01 & 126.05 & 80.42 & 97.65 \\
Wholesale Trade & 0.05 & 107.81 & 105.93 & 94.40 & 119.34 \\
Construction & 0.04 & 153.80 & 258.22 & 139.18 & 272.83 \\
Mining & 0.02 & 148.34 & 203.70 & 163.87 & 188.16 \\
Services & 0.03 & 115.16 & 162.65 & 119.19 & 158.62 \\
Transport & 0.03 & 103.08 & 55.43 & 81.38 & 77.13 \\
\hline
\end{tabular}

Notes: ROA - measure of return on assets; ACP - number of days for collection; INV - number of inventory days; APP - number of days for payment; CCC - cash conversion cycle.

As expected, it can be seen that firms in the retail sector present the lowest number of collections days, approximately 52 days, which means that they took less time to collect payments from their customers. The sector with the largest warehouse stock is the construction sector, while the transport sector presents the lowest. With regard to the number of payment days, retailers (80.42 days) are the fastest to pay their suppliers. Firms in the mining and construction sector took on average more than 163 days to pay their suppliers. However, these are also the sectors that take the longest to collect from their customers. Taking into consideration all these periods in conjunction, it can be seen that the transport sector presents a CCC that is substantially lower than the other sectors. This can be explained in part by the low number of inventory days. In contrast, the construction and mining industries are the sectors that take most time to generate cash in hand (272 and 
188 days on average, respectively), hence their need to obtain more resources to finance their operations.

Table 3 presents the descriptive statistics of the variables used in this study.

Table 3 - Descriptive Statistics

\begin{tabular}{ccccccc}
\hline & Average & Median & Maximum & Minimum & $\begin{array}{c}\text { Standard } \\
\text { Deviation }\end{array}$ & Observations \\
\hline ROA & 0.041735 & 0.034482 & 1.228640 & -34.01411 & 0.119235 & 219643 \\
APP & 115.1716 & 93.15057 & 1093.697 & 0.000140 & 99.11091 & 219643 \\
ACP & 107.4815 & 94.95747 & 1094.709 & 0.000202 & 87.41852 & 219643 \\
INV & 152.3077 & 98.88458 & 1094.979 & $3.07 \mathrm{E}-06$ & 167.1723 & 219643 \\
CCC & 144.6176 & 99.55209 & 2004.541 & $3.97 \mathrm{E}-05$ & 154.4791 & 219643 \\
DTI & 0.233775 & 0.211042 & 4.781606 & -0.355586 & 0.200012 & 219643 \\
CLR & 1.983365 & 1.418000 & 99.01700 & 0.017000 & 2.293593 & 219643 \\
TA & 9.365137 & 5.659382 & 1240.376 & 0.009102 & 13.22311 & 219643 \\
BOARD & 3.373165 & 3.000000 & 125.0000 & 0.000000 & 2.933032 & 219643 \\
SGR & -0.040658 & -0.030011 & 13.19828 & -0.996479 & 0.236604 & 219643 \\
GDPGR & -0.010436 & -0.010000 & 0.083000 & -0.147000 & 0.028127 & 219643 \\
\hline
\end{tabular}

The firms in this sample, on average, present assets of approximately 9.36 million euros, with an average operating profitability of $4.12 \%$. The average number of collection days is 107 , which is quite similar to the number of payment days, 115 . The minimum number of days for collection from customers is 0 and the maximum number of days is 1095 . The maximum number of days for firms to pay suppliers is 1094. On average 152 days are needed to sell products in stock, with a deviation of 167 . The firms in this sample have, on average, a cash conversion cycle of 145 days. The median is 100 days.

The average number of directors is 3, with a standard deviation of around 2.99.

Debt to income ratio, current liquidity ratio, sales growth and the GDP growth were used as control variables. The current liquidity ratio, considered the traditional measure of liquidity, is on average 1.98, with a standard deviation of 2.29. On average, the firms in this sample present a annual percentage fall in sales growth of around $4 \%$. The percentage of total assets financed by creditors represents approximately $24 \%$. The maximum debt to income ratio corresponds to 4.78 , which is unusual, but if the hypothesis of firms having 
negative capital is considered, this may be possible. In the period in question, the GDP fell approximately $1 \%$ on average.

It is to be noted that the sample in question included a diversity of countries and sectors, with their own characteristics that may influence the results.

Table 4 presents the correlation coefficients for the dependent variable and the independent variables. The aim of this analysis was to verify the existing relationship between the variables under consideration.

Table 4 - Correlation Matrix

\begin{tabular}{|c|c|c|c|c|c|c|c|c|c|c|c|}
\hline $\begin{array}{l}\text { Correlation } \\
\text { Profitability }\end{array}$ & $\overline{\mathrm{CCC}}$ & APP & $\overline{\mathrm{ACP}}$ & INV & $\overline{\text { ROA }}$ & DTI & $\overline{C L R}$ & TA & BOARD & $\overline{\text { SGR }}$ & $\begin{array}{c}\text { GDPG } \\
\text { R }\end{array}$ \\
\hline $\mathrm{CCC}$ & 1.000000 & & & & & & & & & & \\
\hline $\mathbf{A P P}$ & $\begin{array}{c}0.132272 \\
(0.0000)\end{array}$ & $\begin{array}{c}1.000000 \\
----\end{array}$ & & & & & & & & & \\
\hline $\mathbf{A C P}$ & $\begin{array}{c}0.417658 \\
(0.0000)\end{array}$ & $\begin{array}{c}0.355032 \\
(0.0000)\end{array}$ & $\begin{array}{c}1.000000 \\
-----\end{array}$ & & & & & & & & \\
\hline INV & $\begin{array}{c}0.784087 \\
(0.0000)\end{array}$ & $\begin{array}{c}0.529440 \\
(0.0000)\end{array}$ & $\begin{array}{c}0.073508 \\
(0.0000)\end{array}$ & 1.000000 & & & & & & & \\
\hline ROA & $\begin{array}{c}-0.075350 \\
(0.0000)\end{array}$ & $\begin{array}{c}-0.044940 \\
(0.0000)\end{array}$ & $\begin{array}{c}-0.099445 \\
(0.0000)\end{array}$ & $\begin{array}{c}-0.044270 \\
(0.0000)\end{array}$ & $\begin{array}{l}1.000000 \\
(0.0000)\end{array}$ & & & & & & \\
\hline DTI & $\begin{array}{c}0.115385 \\
(0.0000)\end{array}$ & $\begin{array}{c}0.055992 \\
(0.0000)\end{array}$ & $\begin{array}{c}0.073848 \\
(0.0000)\end{array}$ & $\begin{array}{c}0.101203 \\
(0.0000)\end{array}$ & $\begin{array}{c}-0.153141 \\
(0.0000)\end{array}$ & 1.000000 & & & & & \\
\hline CLR & $\begin{array}{c}0.123695 \\
(0.0000)\end{array}$ & $\begin{array}{c}-0.151838 \\
(0.0000)\end{array}$ & $\begin{array}{c}-0.021588 \\
(0.0000)\end{array}$ & $\begin{array}{c}0.035572 \\
(0.0000)\end{array}$ & $\begin{array}{c}0.093525 \\
(0.0000)\end{array}$ & $\begin{array}{c}-0.278159 \\
(0.0000)\end{array}$ & $\begin{array}{c}1.000000 \\
-----\end{array}$ & & & & \\
\hline TA & $\begin{array}{c}0.189458 \\
(0.0000)\end{array}$ & $\begin{array}{c}0.063322 \\
(0.0000)\end{array}$ & $\begin{array}{c}0.136906 \\
(0.0000)\end{array}$ & $\begin{array}{c}0.141023 \\
(0.0000)\end{array}$ & $\begin{array}{c}-0.020970 \\
(0.0000)\end{array}$ & $\begin{array}{c}0.069627 \\
(0.0000)\end{array}$ & $\begin{array}{c}0.050809 \\
(0.0000)\end{array}$ & 1.000000 & & & \\
\hline BOARD & $\begin{array}{c}0.043993 \\
(0.0000)\end{array}$ & $\begin{array}{c}-0.039333 \\
(0.0000)\end{array}$ & $\begin{array}{c}-0.020729 \\
(0.0000)\end{array}$ & $\begin{array}{c}0.028173 \\
(0.0000)\end{array}$ & $\begin{array}{c}-0.034453 \\
(0.0000)\end{array}$ & $\begin{array}{c}-0.021015 \\
(0.0000)\end{array}$ & $\begin{array}{c}0.006872 \\
(0.0013)\end{array}$ & $\begin{array}{c}0.274679 \\
(0.0000)\end{array}$ & 1.000000 & & \\
\hline SGR & $\begin{array}{c}-0.090189 \\
(0.0000)\end{array}$ & $\begin{array}{c}0.241407 \\
(0.0000)\end{array}$ & $\begin{array}{c}-0.177334 \\
(0.0000)\end{array}$ & $\begin{array}{c}0.152513 \\
(0.0000)\end{array}$ & $\begin{array}{c}0.186806 \\
(0.0000)\end{array}$ & $\begin{array}{c}0.000495 \\
(0.8165)\end{array}$ & $\begin{array}{c}-0.029186 \\
(0.0000)\end{array}$ & $\begin{array}{c}0.021225 \\
(0.0000)\end{array}$ & $\begin{array}{c}0.040159 \\
(0.0000)\end{array}$ & $\begin{array}{c}1.000000 \\
----\end{array}$ & \\
\hline GDPGR & $\begin{array}{c}-0.002219 \\
(0.2983)\end{array}$ & $\begin{array}{c}0.015807 \\
(0.0000)\end{array}$ & $\begin{array}{c}-0.085344 \\
(0.0000)\end{array}$ & $\begin{array}{c}0.051949 \\
(0.0000)\end{array}$ & $\begin{array}{c}0.069404 \\
(0.0000)\end{array}$ & $\begin{array}{c}-0.066208 \\
(0.0000)\end{array}$ & $\begin{array}{c}0.028616 \\
(0.0000)\end{array}$ & $\begin{array}{c}-0.008138 \\
(0.0000)\end{array}$ & $\begin{array}{c}0.021269 \\
(0.0000)\end{array}$ & $\begin{array}{c}0.264613 \\
(0.0000)\end{array}$ & $\begin{array}{c}1.000000 \\
----\end{array}$ \\
\hline
\end{tabular}

Note: The p-values are in brackets.

In Table 4, we can see that the return on assets (ROA) is negatively correlated with the cash conversion cycle (CCC), average collection period (ACP), average payment period (APP) and average inventory period (INV). Analysis of the correlation of the ACP shows a negative coefficient of -0.099445 (p-value of 0.000 ) with statistical significance at $1 \%$. This inverse relationship between ACP and ROA means that an increase in the average collection period negatively affects profitability. The CCC also presents a negative coefficient of -0.075350 ( $\mathrm{p}$-value of 0.0000 ), with statistical significance at $1 \%$, which 
means that if a firm is able to reduce its CCC then it will be able to improve its profitability. Similarly, there is a negative correlation between APP and ROA, with a cross-correlation coefficient of -0.044940 (p-value of 0.0000), with statistical significance at $1 \%$. This means that less profitable firms tend to take longer to pay their debts. The correlation between INV and ROA indicates the same type of result. The coefficient is negative, -0.044270 ( $\mathrm{p}$-value of 0.000 ) and significant. For which reason, the less time the stock remains in the warehouse, the greater the profitability.

The number of directors has a negative relationship with profitability, the coefficient of which is -0.034453 ( $\mathrm{p}$-value of 0.0000 ). This relationship shows that a smaller board will tend to achieve better levels of profitability, which can be explained by the fact that a smaller board tends to be more efficient in the supervision and control of decision-making.

The current liquidity ratio has a positive relationship with ROA. The coefficient is 0.093525 ( $\mathrm{p}$-value is 0.000 ). Total assets, as well as the debt to income ratio, have a negative and significant relationship with profitability. In contrast, the other control variables, such as sales growth and GDP, have a positive and significant relationship with ROA.

Analysis of the correlation matrix shows that firms that are able to reduce their average collection periods, average payment periods and average inventory days will tend to obtain higher levels of profitability.

\subsection{Econometric analysis}

This section is divided into four parts. The first part presents the results of the econometric analysis for the European context. The second part presents the results of the coefficients by country. The third part provides further details of the results of the first part. Finally, an additional analysis is made using return on equity (ROE) as a dependent variable instead of return on assets (ROA). 


\subsubsection{European context}

The cash conversion cycle, as well as the proxies, such as APP, INV and ACP, will be used to assess the impact of working capital management on the profitability of firms, considering their return on assets. In accordance with the previous section, the models used will be esteemed using the GLS method with cross-section weights and the pooled OLS method. The individual effects by country, sector and year will also be included in this analysis (through binary variables). The results are presented in the table below. The coefficients of the dummies will only be presented in the following subsections. 
Table 5 - Relationship between working capital management and profitability (2008 to 2013) with GLS cross section weights and pooled OLS estimation method

\begin{tabular}{|c|c|c|c|c|c|c|c|c|c|c|c|c|c|c|c|c|}
\hline \multicolumn{17}{|c|}{ Dependent variable: ROA } \\
\hline & \multicolumn{4}{|c|}{ GLS (cross-section weights) } & \multicolumn{4}{|c|}{ GLS (cross-section weights) } & \multicolumn{4}{|c|}{ Pooled OLS } & \multicolumn{4}{|c|}{ Pooled OLS } \\
\hline $\begin{array}{c}\text { Independent } \\
\text { variables }\end{array}$ & $\begin{array}{r}\text { I } \\
\text { coeff }\end{array}$ & $\begin{array}{c}\text { II } \\
\text { Coeff }\end{array}$ & $\begin{array}{c}\text { III } \\
\text { coeff }\end{array}$ & $\begin{array}{c}\text { IV } \\
\text { Coeff }\end{array}$ & $\begin{array}{c}\text { I } \\
\text { Coeff }\end{array}$ & $\begin{array}{c}\text { II } \\
\text { Coeff }\end{array}$ & $\begin{array}{c}\text { III } \\
\text { Coeff }\end{array}$ & $\begin{array}{c}\text { IV } \\
\text { coeff }\end{array}$ & $\begin{array}{c}\text { I } \\
\text { Coeff }\end{array}$ & $\begin{array}{c}\text { II } \\
\text { Coeff }\end{array}$ & $\begin{array}{c}\text { III } \\
\text { Coeff }\end{array}$ & $\begin{array}{c}\text { IV } \\
\text { Coeff }\end{array}$ & $\begin{array}{c}\text { I } \\
\text { coeff }\end{array}$ & $\begin{array}{c}\text { II } \\
\text { coeff }\end{array}$ & $\begin{array}{c}\text { III } \\
\text { coeff }\end{array}$ & $\begin{array}{c}\text { IV } \\
\text { coeff }\end{array}$ \\
\hline $\mathrm{C}$ & $8.274780^{* * * *}$ & $8.387241 * * *$ & $8.372385^{* * *}$ & $8.084877 * * *$ & $6.807550 * * *$ & $7.511226 * * *$ & $6.506164 * * *$ & $6.488496 * * *$ & $8.668251 * * *$ & $9.011304^{* * *}$ & $8.813132^{* * *}$ & $8.642380 * * *$ & $7.099746 * * *$ & $7.658668 * * *$ & $6.867402 * * *$ & $6.654567 * * *$ \\
\hline $\mathrm{ACP}$ & $-0.005441^{* * * *}$ & & & & -0.0083 & $377^{* * *}$ & & & -0.005 & $07 * * *$ & & & -0.008 & $52^{* * * *}$ & & \\
\hline APP & & $-0.007284 * * *$ & & & & -0.009 & $16^{* * *}$ & & & -0.007 & $85 * * *$ & & & -0.010 & $151 * * *$ & \\
\hline INV & & & $-0.003908 * * *$ & & & & -0.004 & $544^{* * * *}$ & & & -0.003 & $991 * * *$ & & & -0.0046 & $48 * * *$ \\
\hline $\mathrm{CCC}$ & & & & $-0.003627^{* * * *}$ & & & & $-0.004092^{* * *}$ & & & & $-0.003508^{* * *}$ & & & & $0.004144^{* * *}$ \\
\hline DTI & $-7.769507 * * *$ & $-7.559891 * * *$ & $-7.754276^{* * *}$ & $-7.482281^{* * * *}$ & $-7.430742 * * *$ & $-7.585729 * * *$ & $-6.860118^{* * *}$ & $-6.924859^{* * *}$ & $-8.310117 * * *$ & $-8.454597 * * *$ & $-8.070137 * * *$ & $-8.023371^{* * *}$ & $-8.042791 * * *$ & $-8.217395 * * *$ & $-7.794198 * * *$ & $7.752142 * * *$ \\
\hline CLR & $0.233318 * * *$ & $0.233699 * * *$ & $0.287295^{* * *}$ & $0.338031 * * *$ & $0.291189^{* * *}$ & $0.210765^{* * *}$ & $0.349794 * * *$ & $0.326163 * * *$ & $0.281986 * * *$ & $0.241260^{* * *}$ & $0.301958^{* * *}$ & $0.318669 * * *$ & $0.308960^{* * *}$ & $0.250207^{* * *}$ & $0.336644 * * *$ & $0.357713 * * *$ \\
\hline BOARD & $-0.248858 * * *$ & $-0.209452 * * *$ & $-0.247358 * * *$ & $-0.182166 * * *$ & $-0.203870^{* * * *}$ & $-0.227114 * * *$ & $-0.189380^{* * * *}$ & $-0.190329^{* * *}$ & $-0.226535 * * *$ & $-0.231602 * * *$ & $-0.221343^{* * * *}$ & $-0.220125^{* * * *}$ & $-0.215366^{* * *}$ & $-0.226846^{* * *}$ & $-0.202419 * * *$ & $0.198852^{-} * * *$ \\
\hline $\mathrm{LOG}(\mathrm{TA})$ & $0.158180 * * *$ & $0.074383^{* * * *}$ & $0.220314^{* * *}$ & $0.169208 * * *$ & $0.191781 * * *$ & $0.138794 * * *$ & $0.112175^{* * *}$ & $0.088055^{* * * *}$ & $0.165381 * * *$ & $0.163471^{* * *}$ & $0.192758^{* * * *}$ & $0.194935^{* * *}$ & $0.211760^{* * *}$ & $0.197638^{* * *}$ & $0.183054 * * *$ & $0.190066^{* * * *}$ \\
\hline GDPGR & $18.98865 * * *$ & $14.49661^{* * * *}$ & $15.07975^{* * *}$ & $19.23889 * * *$ & $0.983089 * * *$ & $3.632680 * * *$ & $1.359345^{* * * *}$ & $5.010637 * * *$ & $21.45922 * * *$ & $19.66748 * * *$ & $21.42231^{* * *}$ & $22.26046 * * *$ & $3.640737 * * *$ & $2.936651 * * *$ & $5.012322 * * *$ & $5.161039 * * *$ \\
\hline SGR & $8.366531^{* * * *}$ & $9.388244 * * *$ & $9.141629 * * *$ & $8.350126 * * *$ & $8.362427 * * *$ & $9.923269^{* * *}$ & $9.344498^{* * *}$ & $8.194296 * * *$ & $8.891563^{* * *}$ & $10.10927 * * *$ & $9.706762^{* * *}$ & $9.051200^{* * * *}$ & $8.878585^{* * *}$ & $10.46227 * * *$ & $9.888833^{* * *}$ & $9.140848^{* * * *}$ \\
\hline $\begin{array}{c}\text { Sector } \\
\text { Dummy }\end{array}$ & yes & yes & yes & yes & no & no & no & no & yes & yes & yes & yes & no & no & no & no \\
\hline $\begin{array}{l}\text { Country } \\
\text { Dummy }\end{array}$ & Yes & yes & yes & yes & no & no & no & no & yes & yes & yes & yes & no & no & no & no \\
\hline $\begin{array}{c}\text { Year } \\
\text { Dummy }\end{array}$ & Yes & yes & yes & yes & no & no & no & no & yes & yes & yes & yes & no & no & no & no \\
\hline $\mathrm{R}^{2}$ & 0.973795 & 0.839085 & 0.986683 & 0.978726 & 0.790358 & 0.882435 & 0.867877 & 0.780885 & 0.081390 & 0.083009 & 0.082560 & 0.081788 & 0.067417 & 0.070447 & 0.068025 & 0.066673 \\
\hline Adjusted $\mathrm{R}^{2}$ & 0.973792 & 0.839064 & 0.986681 & 0.978723 & 0.790352 & 0.882432 & 0.867873 & 0.780878 & 0.081268 & 0.082888 & 0.082438 & 0.081667 & 0.067387 & 0.070417 & 0.067995 & 0.066643 \\
\hline F-statistic & $281416.8^{* * * *}$ & $39488.33 * * *$ & $561074.9^{* * *}$ & $348398.0^{* * * *}$ & $118290.6 * * *$ & $235510.2 * * *$ & $206102.5^{* * *}$ & $111819.4 * * *$ & $670.9631 * * *$ & $685.5191^{* * *}$ & $681.4739^{* * *}$ & $674.5377 * * *$ & $2268.210^{* * * *}$ & $2377.880^{* * * *}$ & $2290.177^{* * *}$ & $2241.409 * * *$ \\
\hline Observations & 219643 & 219643 & 219643 & 219643 & 219643 & 219643 & 219643 & 219643 & 219643 & 219643 & 219643 & 219643 & 219643 & 219643 & 219643 & 219643 \\
\hline
\end{tabular}

Notes: *** - significance at 1\%; ** - significance at 5\%; * significance at 10\%. ACP - Average collection period; APP - Average payment period; INV - Average inventory period; CCC - Cash conversion cycle; DTI Debt to income ratio; CLR - Current liquidity ratio; Board - Number of directors; Log(TA) - Firm size; GDPGR- Annual growth rate of GDP; SGR- Sales growth. 
An analysis of the table above shows that the outcomes of the estimates are more consistent, using both the OLS method and the GLS method, when the dummies are introduced for sector, country and year. The introduction of dummy variables in the models can control differences between individuals (heterogeneity). The explanatory power of R-squared also increases with the introduction of dummy variables.

The problem of heterogeneity resulting from the huge diversity of the firms in the sample can be controlled by accepting the hypothesis of heteroscedasticity (in other words nonconstant variance in random disturbances), by using the General Least Squares (GLS) method with cross-section weights. Bearing this in mind, the analysis of the results focuses on the GLS estimates with cross-section weights and dummies for country, year and sector.

In model I, presented in Table 5, the results suggest that the coefficients of all the variables are statistically significant at $1 \%$. The coefficient of the average collection period is negatively associated with profitability. This result shows that the shorter the average collection period for sales, the greater the operating profitability, since cash holdings increase. In other words, it is consistent with the view of Raheman and Nasr (2007) that an increase in the number of collection days reduces profitability. This result confirms hypothesis $\mathrm{H} 2$.

According to the literature, the logarithm of total assets used as proxy for the size of firms has a positive and significant relationship with profitability, which means that the larger the size of a firm, the greater its profitability. In addition, the growth of firms can be an important indicator of new business opportunities that enable profitability to be improved, which can be confirmed by the positive association between sales growth and ROA. As expected, profitability also improves in periods of greater economic growth.

Analysis of the effect of the CG measure on profitability reveals that there is a negative association between the number of directors and profitability. These results confirm hypothesis H5, that CG measures have an impact on profitability. The same results were found in studies by Yermack (1996) and Ukaegbu (2014). The negative association found between ROA and the number of directors can be attributed to the fact that a larger board generates communication and decision problems, which may lead to disagreement among directors. 
An increase in borrowing implies a reduction of profitability, as is shown by the coefficient of the debt to income ratio. The current liquidity ratio, used as a measure of liquidity, has a positive and significant relationship with profitability, contrary to expectations. However, there are also reasons for the liquidity-profitability relationship to be positive. According to Hirigoyen (1985), if a firm has high levels of profitability and low levels of liquidity, it has to rely on loans to cover its operating expenses. As cheaper sources of financing are rapidly used up, interest rates tend to rise. When interest rates rise, credit risk increases, leading to an increase in the rates charged by financial backers. Given this scenario, the firm will have to extend payment times to suppliers, which implies more expensive purchases of raw materials. In addition, it would no longer be eligible for financial discounts and would incur interest and fines because of the delays in payments accounts. This cycle would therefore jeopardise profitability and further compound the problem of liquidity. In contrast, a firm with high liquidity and low profitability does not generate sufficient funds to finance its activities, which ultimately jeopardises its liquidity. For this reason, the interaction between them must lead to the target of flexibility.

Studies such as Bruinshoofd and Kool (2002) and Braga et al. (2003) also support the existence of a positive relationship, insofar as an increase in liquidity can be a consequence of positive operating and financial results. Thus, high profitability strengthens liquidity, which means that investments can be self-financed. With sufficient liquidity, investments boost growth and future profitability in a virtuous cycle. In contrast, low levels of liquidity may lead to higher borrowing requirements and a reduction in the levels of return on investments. In this respect, low profitability does not generate sufficient liquidity nor selffinancing of investments, which ultimately hinders future growth and profitability in a vicious circle. Mikkelson and Partch (2002) note that liquidity does not hinder performance. Harford et al. (2003) found that maintaining certain levels of cash can resemble a reserve capacity for possible investments in downturns, reflected in better operating performance and higher post-downturn growth.

Likewise, the positive relationship between liquidity and profitability is consistent with the pecking order theory of Myers (1984) and Myers and Majluf (1984), since firms use first of all the amount generated and accumulated internally before seeking external funds. 
The adjusted R-squared is 0.973795 and reveals the explanatory power of the model which is globally significant at a significance level of $1 \%$ (F-value 281416 and p-value 0.0000 ).

The second column in Table 5 presents the estimation results for model II with average payment period as the measure of working capital management. The same control variables were used as in the previous regression. It was verified that there is a negative relationship between average payment period and ROA. This association is consistent with various studies, including Deloof (2003) and Lazaridis and Tryfonidis (2006), which claim that less profitable firms take more time to pay their debts. These results confirm hypothesis H3. Firm size, liquidity, and GDP and sales growth have a positive impact on profitability. The relationship between the debt to income ratio and number of directors variables is the opposite. The model is globally significant (F-value of 39488.33). The adjusted R-squared is approximately 0.839085 .

In model III, the average inventory period variable was used as an independent variable instead of the average payment period used in the previous model. The coefficient of INV is negative and statistically significant. This means that if stock remains longer in the warehouse, without being sold, this has a negative effect on the firm's operating profitability. Hypothesis $\mathrm{H} 4$ is supported by these results. The debt to income ratio and the number of directors affect profitability and have negative coefficients. And as in model I, the other control variables such as current liquidity ratio, the logarithm of assets, GDP growth and sales growth positively affect the profitability of firms.

The adjusted R-squared is 0.986681 . The model is globally significant (F-value 561074.9).

The estimation of model IV uses the same control variables as the preceding models, as well as the cash conversion cycle variable, as independent variables. As the literature suggests, the CCC shows an inverse and statistically significant relationship with profitability. This means that a reduction in the CCC positively affects profitability. These results confirm hypothesis $\mathrm{H} 1$. The control variables are all significant and present the same signs as the preceding models. The adjusted R-squared of this model is at 0.978726 with an F-value of 348398.0 (p-value 0.0000), which means that the jointly analysed explanatory variables are not rejected, for which reason the model is globally significant. 
Table 6 - Relationship between working capital management and profitability (2008 to 2013): Regression with fixed effects (fixed cross-section)

\begin{tabular}{|c|c|c|c|c|}
\hline \multicolumn{5}{|c|}{ Dependent variable: ROA } \\
\hline \multicolumn{5}{|c|}{ fixed cross-section } \\
\hline & I & II & III & IV \\
\hline Independent variables & Coeff & Coeff & Coeff & Coeff \\
\hline $\mathrm{C}$ & $1.776174 * * *$ & $1.881680 * * *$ & $1.422836 * * *$ & $1.292308 * * *$ \\
\hline $\mathrm{ACP}$ & $-0.009837 * * *$ & & & \\
\hline APP & & $-0.007118 * * *$ & & \\
\hline INV & & & $-0.001958 * * *$ & \\
\hline $\mathrm{CCC}$ & & & & $-0.001118 * * *$ \\
\hline DTI & $-14.09379 * * *$ & $-14.68400 * * *$ & $-14.29311^{* * *}$ & $-14.22768 * * *$ \\
\hline CLR & $0.070870^{* * *}$ & 0.043223 & $0.068807 * * *$ & $0.072361 * * *$ \\
\hline BOARD & $-0.075573 * * *$ & $-0.075849 * * *$ & $-0.074307 * * *$ & $-0.074355^{* * *}$ \\
\hline LOG(TA) & $4.281256^{* * *}$ & $4.224878 * * *$ & $4.081795 * * *$ & $4.055580 * * *$ \\
\hline GDPGR & $4.542289 * * *$ & $4.413357 * * *$ & $4.237948 * * *$ & $4.179148 * * *$ \\
\hline SGR & $5.826598 * * *$ & $7.214366^{* * *}$ & $6.551261 * * *$ & $6.184511 * * *$ \\
\hline Dummy sector & no & no & no & no \\
\hline Dummy country & no & no & no & no \\
\hline Dummy year & no & no & no & no \\
\hline $\mathrm{R}^{2}$ & 0.476613 & 0.476636 & 0.475903 & 0.475803 \\
\hline Adjusted $\mathrm{R}^{2}$ & 0.324925 & 0.324955 & 0.324010 & 0.323881 \\
\hline F-statistic & $3.142068 * * *$ & $3.142359 * * *$ & $3.133140 * * *$ & $3.131888 * * *$ \\
\hline Observations & 219643 & 219643 & 219643 & 219643 \\
\hline
\end{tabular}

Notes: *** - significance at 1\%; ** - significance at 5\%; - significance at 10\%. ACP - Average collection period; APP - Average payment period; INV - Average inventory period; CCC - Cash conversion cycle; DTI - Debt to income ratio; CLR - Current liquidity ratio; Board - Number of directors; $\log ($ TA) - Firm size; GDPGR- Annual growth rate of GDP; SGR- Sales growth.

The other estimations present in Table 5, which do not consider the dummies for country, year and sector, for the OLS and GLS methods present results similar to those analysed above. All the management working capital proxies (ACP, APP, INV and CCC) present negatives and significant coefficients. And when the dummy variables are introduced, the coefficients are still negative and significant.

For comparison purposes, cross-section fixed effects were estimated. The results are presented in the following table.

Table 6 demonstrates that the average collection period, average payment period, average inventory period and cash conversion cycle present negative and significant coefficients, as set out in Table 5. The debt to income ratio and number of directors also have an inverse and significant relationship with profitability. The other control variables, such as GDP 
growth and sales, as well as the logarithm of assets present positive and significant coefficients, as set out in the preceding table. However, the current liquidity ratio is no longer statistically significant when model II is estimated, with the average payment period variable.

\subsubsection{Analysis by country}

This section will analyse whether there are significant differences between countries in the sample under investigation, in relation to working capital management. For this purpose, the method of GLS with cross-section weights will be used. The results of the estimation are presented in the table below. 
Table 7 - Relationship between working capital management and profitability per country (2008 to 2013): GLS with cross-section weights

\begin{tabular}{|c|c|c|c|c|c|c|c|c|c|c|c|c|}
\hline \multicolumn{13}{|c|}{ Dependent variable: ROA } \\
\hline \multirow{2}{*}{$\begin{array}{l}\text { Independent } \\
\text { variables }\end{array}$} & \multirow[b]{2}{*}{ Austria } & \multirow[b]{2}{*}{ Belgium } & \multirow[b]{2}{*}{ Estonia } & \multirow[b]{2}{*}{ Finland } & \multicolumn{3}{|c|}{ GLS (cross-section weights) } & \multirow[b]{2}{*}{ Luxembourg } & \multirow[b]{2}{*}{ Portugal } & \multirow[b]{2}{*}{ Slovakia } & \multirow[b]{2}{*}{ Slovenia } & \multirow[b]{2}{*}{ Spain } \\
\hline & & & & & Germany & Italy & Latvia & & & & & \\
\hline $\mathrm{C}$ & $3.111372 *$ & $8.730835 * * *$ & $7.640397^{* * *}$ & $10.76550^{* * *}$ & $12.51933^{* * *}$ & $5.370435^{* * *}$ & $13.29663^{* * *}$ & $8.921189 * *$ & $5.829519^{* * *}$ & $7.211248^{* * *}$ & $5.607064^{* * *}$ & $9.615663^{* * *}$ \\
\hline $\mathrm{CCC}$ & 0.004261 & $-0.004425^{* * *}$ & $-0.005136^{* * *}$ & $-0.002306 * * *$ & $-0.005797 * * *$ & $-0.003601 * * *$ & $-0.012414^{* *}$ & -0.003931 & $-0.001671^{* * *}$ & $-0.007645 * * *$ & $-0.001811^{* * *}$ & $-0.001511^{* * *}$ \\
\hline DTI & $-6.826596 * *$ & $-11.27137 * * *$ & $-9.733908^{* * *}$ & $-9.966678^{* * *}$ & $-5.796163 * * *$ & $-6.395987^{* * *}$ & -0.470082 & -5.826541 & $-9.008875^{* * *}$ & $-5.950215^{* * *}$ & $-6.748096 * * *$ & $-8.137218^{* * *}$ \\
\hline CLR & 1.413799 & $0.182999 * * *$ & $0.382047^{* * *}$ & $0.321943^{* * *}$ & $0.406674^{* * *}$ & $0.347506^{* * *}$ & 0.050834 & 0.009267 & $0.913595^{* * *}$ & $0.343626^{* * *}$ & $0.379055^{* * *}$ & $0.086060^{* * *}$ \\
\hline BOARD & $0.614683^{* *}$ & $-0.134327^{* * *}$ & $-0.423597 * * *$ & $-0.390625 * * *$ & $-0.200172 * * *$ & $-0.194279 * * *$ & $-1.560903 * * *$ & $-2.005248^{* * *}$ & $-0.092323 * * *$ & $-0.676017^{* * *}$ & $-0.107043^{* * *}$ & $-0.197920 * * *$ \\
\hline LOG(TA) & -0.386376 & $-0.235062 * * *$ & $1.653394^{* * *}$ & $-0.100765 * * *$ & $-1.321934 * * *$ & $0.290521^{* * *}$ & 0.876906 & $3.449611^{* * *}$ & $0.341189 * * *$ & $0.343988^{* * *}$ & $0.256917^{* * *}$ & $-0.754951 * * *$ \\
\hline GDPGR & 4.140670 & $-12.49724^{* * *}$ & -0.203023 & $-20.34321^{* * *}$ & 0.481945 & $-6.418548^{* * *}$ & $31.85688^{* *}$ & -34.87990 & $6.169091^{* * *}$ & $4.436032^{* * *}$ & $-3.568054^{* * *}$ & $16.41732^{* * *}$ \\
\hline SGR & $6.906607^{* * *}$ & $8.936051^{* * *}$ & $13.66390^{* * *}$ & $15.24553^{* * *}$ & $12.53993^{* * *}$ & $7.950878^{* * *}$ & $11.54958^{* * *}$ & 11.85490 & $5.901039 * * *$ & $10.54821^{* * *}$ & $9.072836^{* * *}$ & $4.255466^{* * *}$ \\
\hline Dummy sector & no & no & no & no & no & no & no & no & no & no & no & no \\
\hline Dummy year & no & no & no & no & no & no & no & no & no & no & no & no \\
\hline $\mathrm{R}^{2}$ & 0.228875 & 0.514106 & 0.762913 & 0.718909 & 0.374485 & 0.865631 & 0.288949 & 0.299261 & 0.578798 & 0.478783 & 0.849519 & 0.978743 \\
\hline Adjusted $\mathrm{R}^{2}$ & 0.211234 & 0.513935 & 0.762413 & 0.718682 & 0.373656 & 0.865624 & 0.218845 & 0.226050 & 0.578144 & 0.478551 & 0.849290 & 0.978736 \\
\hline F-statistic & $12.97465^{* * *}$ & $3022.726^{* * *}$ & $1525.264^{* * *}$ & $3173.202^{* * *}$ & $452.0901^{* * *}$ & $125477.2^{* * *}$ & $4.121742^{* * *}$ & $4.087623^{* * *}$ & $884.9567^{* * *}$ & $2070.359 * * *$ & $3706.575^{* * *}$ & $135455.5^{* * *}$ \\
\hline Observations & 314 & 20006 & 3326 & 8693 & 5294 & 136350 & 79 & 75 & 4516 & 15785 & 4604 & 20601 \\
\hline
\end{tabular}

Notes: *** - significance at 1\%; ** - significance at 5\%; * - significance at 10\%. ACP - Average collection period; APP - Average payment period; INV - Average inventory period; CCC Cash conversion cycle; DTI - Debt to income ratio; CLR - Current liquidity ratio; Board - Number of directors; Log(TA) - Firm size; GDPGR- Annual growth rate of GDP; SGR- Sales growth. 
The dummy variables for country and sector were not included in the estimation because some countries did not have sufficient observations to be able to estimate regressions under these conditions.

According to Table 7, the cash conversion cycle presents a negative and significant coefficient for all countries except for Austria and Luxembourg, which is no longer statistically significant. This means that the shorter the cash conversion cycle (CCC) in European countries, the higher the levels of profitability. These results are consistent with those obtained by the estimation of all the countries in conjunction.

With regard to the remaining variables, the coefficients of the debt to income ratio, current liquidity ratio, number of directors and sales growth are in accordance with the results obtained above. Nevertheless, for the logarithm of assets and GDP growth the results are not consistent for all the countries in the sample.

In short, it can be seen that working capital management can be used by firms to affect their profitability.

\subsubsection{Temporal analysis}

Economic conditions change over time. The recent financial crisis has affected many countries, especially in Europe. The next table therefore seeks to show whether economic changes over the last few years have had an impact on the profitability of firms.

To analyse temporal differences, the following table presents details of the coefficients of the year dummy variable for model IV in Table 5, estimated using the GLS method with cross-section weights and dummies for sector, year and country. The coefficients were calculated in relation a reference categorical variable for sector, country and year. The reference categoric variables are the industrial sector, the country Austria and the year 2008. 
Table 8 - Relationship between working capital management and profitability per country (2008 to 2013): GLS with cross-section weights (dummy years)

\begin{tabular}{|c|c|}
\hline $\begin{array}{r}\text { Depen } \\
\text { GLS (cross }\end{array}$ & ghts) \\
\hline Independent Variables & Coefficients \\
\hline $\mathrm{C}$ & 8.084877 **** \\
\hline $\mathrm{CCC}$ & $-0.003627 * * *$ \\
\hline DTI & $-7.482281 * * *$ \\
\hline CLR & $0.338031 * * *$ \\
\hline BOARD & $-0.182166^{* * *}$ \\
\hline LOG(TA) & $0.169208^{* * *}$ \\
\hline GDPGR & $19.23889 * * *$ \\
\hline SGR & $8.350126^{* * * *}$ \\
\hline $\mathrm{YR}=2009$ & $0.048845^{*}$ \\
\hline $\mathrm{YR}=2010$ & $-2.499813 * * *$ \\
\hline $\mathrm{YR}=2011$ & $-2.024755^{* * *}$ \\
\hline $\mathrm{YR}=2012$ & $-1.831626 * * *$ \\
\hline $\mathrm{YR}=2013$ & $-2.369138 * * *$ \\
\hline Dummy country & yes \\
\hline Dummy year & yes \\
\hline $\mathrm{R}^{2}$ & 0.978726 \\
\hline Adjusted $\mathrm{R}^{2}$ & 0.978723 \\
\hline F-statistic & 348398.0 \\
\hline Observations & 219643 \\
\hline
\end{tabular}

Notes: $* * *$ - significance at $1 \%$; ** - significance at $5 \%$; * significance at $10 \%$. ACP - Average collection period; APP - Average payment period; INV - Average inventory period; CCC - Cash conversion cycle; DTI - Debt to income ratio; CLR - Current liquidity ratio; Board - Number of directors; Log(TA) - Firm size; GDPGR- Annual growth rate of GDP; SGR- Sales growth.

The results obtained reflect temporal economic variations. The coefficients for the years 2009 to 2013 are all statistically significant at 10,5 and 1\%, with the exception of 2009 which is only significant at $10 \%$. Profitability has fallen over recent years (since 2010) in comparison with the reference categorical variable (2008).

\subsubsection{Additional robustness analysis}

To assess the robustness of the results, the equations I to IV estimated in Table 5 using the GLS method with cross-section weights were recalculated. However, instead of using the return on assets dependent variable defined by the quotient between EBIT and total assets, an alternative definition was used. The alternative consisted of defining return on equity (ROE) as the quotient between net profit over equity (Baños-Caballero et al. 2012b). In English this corresponds to Return on Equity, ROE, and is used by investors to check whether the return on their investments matches the risk. 


$$
R O E=\frac{\text { resultados liquidos }}{\text { capital próprio }} \times 100
$$

Table 9 - Relationship between working capital management and profitability per country (2008 to 2013): GLS with cross-section weights with alternative dependent variable

\begin{tabular}{|c|c|c|c|c|}
\hline \multicolumn{5}{|c|}{ Dependent Variable: ROE } \\
\hline \multirow[b]{3}{*}{$\begin{array}{l}\text { Independent } \\
\text { Variables }\end{array}$} & \multicolumn{4}{|c|}{ GLS (cross-section weights) } \\
\hline & I & II & III & IV \\
\hline & Coeff. & Coeff. & Coeff. & Coeff. \\
\hline $\mathrm{C}$ & 0.191756 & $1.070492 * * *$ & $0.865852 * * *$ & $0.749148 *$ \\
\hline $\mathrm{ACP}$ & $-0.005080 * * *$ & & & \\
\hline APP & & $-0.002012 * * *$ & & \\
\hline INV & & & $-0.001641 * * *$ & \\
\hline $\mathrm{CCC}$ & & & & $-0.000160 * * *$ \\
\hline DTI & $-9.485837 * * *$ & $-6.922685 * * *$ & $-7.282574 * * *$ & $-6.740522 * * *$ \\
\hline CLR & $0.406102 * * *$ & $0.307472 * * *$ & $0.601947 * * *$ & $0.481247 * * *$ \\
\hline BOARD & $-0.457289 * * *$ & $-0.350791 * * *$ & $-0.432842 * * *$ & $-0.367933 * * *$ \\
\hline LOG(TA) & $1.470223^{* * *}$ & $1.147420 * * *$ & $1.463298 * * *$ & $1.214040 * * *$ \\
\hline GDPGR & $0.6528349 * * *$ & $0.2879185 * * *$ & $0.2940433 * * *$ & $0.2525469 * * *$ \\
\hline SGR & $6.771920 * * *$ & $5.121185 * * *$ & $5.925916 * * *$ & $5.171255 * * *$ \\
\hline Dummy sector & yes & yes & yes & yes \\
\hline Dummy country & yes & yes & yes & yes \\
\hline Dummy year & yes & yes & yes & yes \\
\hline $\mathrm{R}^{2}$ & 0.975436 & 0.813117 & 0.935162 & 0.994817 \\
\hline Adjusted $\mathrm{R}^{2}$ & 0.975432 & 0.813092 & 0.935154 & 0.994817 \\
\hline F-statistic & $300480.1 * * *$ & $32923.48^{* * *}$ & $109139.4 * * *$ & $1452482.0 * * *$ \\
\hline Observations & 219473 & 219473 & 219473 & 219473 \\
\hline
\end{tabular}

Notes: $* * *$ - significance at $1 \%$; $* *$ - significance at 5\%; - significance at $10 \%$. ACP - Average collection period; APP - Average payment period; INV - Average inventory period; CCC - Cash conversion cycle; DTI - Debt to income ratio; CLR - Current liquidity ratio; Board - Number of directors; Log(TA) - Firm size; GDPGR- Annual growth rate of GDP; SGR- Sales growth.

The inverse relationship of the variables ACP, APP, INV and CCC with the alternatively defined dependent variable confirms the results previously obtained. In this respect, the results obtained mean that a policy of reducing INV, ACP and APP to a minimum can increase the profitability of firms. 
The cash conversion cycle can be used for an integrated analysis of the three components of the working capital (INV, ACP and APP) and the results indicate that a reduction in this cycle leads to an increase in profitability. This conclusion is similar to that reached earlier.

With regard to the other variables, the signs of the coefficients of the debt to income ratio and number of directors maintain a negative and significant sign with the dependent variable. In contrast, and as obtained in the previous models, the variables of current liquidity ratio and GDP and sales growth present positive and significant coefficients. 


\section{CONCLUSION}

Financial management of working capital is particularly important in the case of small and medium-sized enterprises (SME), since most of those firms have to effectively manage scarce resources of difficult access in highly competitive environments. This study analyses the relationship between operating performance and short-term financial management for a set of SMEs from 19 European countries, in the period from 2008 to 2013.

The results show conclusions with statistical significance and consistent with existing literature. Analysis of the effect of the CG measure on profitability shows that there is a negative association between the number of directors and profitability, for which reason the hypothesis that CG measures have an impact on profitability is confirmed. The same results were found by Yermack (1996) and Ukaegbu (2014). The negative association found between ROA and the number of directors can be attributed to the fact that a larger board generates communication and decision problems, which may lead to disagreement among directors. In other words, a larger board can be characterised by inefficiency or lack of communication, however larger boards are able to gather more information. Normally, larger boards are associated with larger firms, which is justified by the greater complexity and dimensions of their operations.

This study also shows a negative relationship between operating profitability and the cash conversion cycle (proxy for working capital management). It also shows an inverse and relationship significant between average collection period, average payment period, average inventory period and profitability. These results are consistent, for example, with studies by Raheman and Nasr (2007) and Deloof (2003) that indicate that firms can increase profitability if they reduce collection periods, inventory periods and if they increase payment times.

In order to guarantee better levels of profitability and to ensure shorter collection periods, a firm must have policies that guarantee faster collections from customers, in order to prevent a reduction in cash flow. 
Policies that maximise the delay in paying suppliers may function as a cheap source of financing, used by managers, especially in the case of SMEs with greater difficulties in obtaining external financing. Nevertheless, firms that have greater payment difficulties may ultimately obtain conditions from suppliers that harm their performances, if acceptable limits are exceeded.

Policies that favour maintaining inventories for short periods of time boost profitability, since they imply, for example, reduced maintenance costs. Thus, managers can create value if they reduce the cash conversion cycle which represents the time lag.

With regard to the size of firms, measured using the natural logarithm of assets, the results suggest that an increase in size tends to increase profitability. This conclusion may be associated with several factors, since larger firms are more likely to hire more qualified managers, to use more sophisticated technologies or even to use economies of scale.

The debt to income ratio presents an inverse relationship with profitability, which is as expected, since firms with higher levels of borrowing will tend to be less profitable.

The results show that periods with better economic performances enable higher levels of profitability to be obtained, hence the positive relationship found between GDP growth and profitability. The same relationship was found for sales growth.

Finally, the current liquidity ratio presents a positive and significant relationship with profitability. The discrepancies of this sign with some earlier studies can be explained by the differences between the samples used and the differences in the periods, since firms have changed over time. In addition, firms have different characteristics in terms of business and organisational, operational and financial structure. This positive relationship can be explained by the fact that the generated and accumulated profits increase liquidity and the availability of resources for investments, which in turn generate further profits. It therefore follows that profitability increases liquidity and this in turn increases profitability in a virtuous cycle. On the other hand, low profitability generates neither sufficient liquidity nor self-financing of investments, which ultimately hinders growth and future profitability in a vicious circle. 
In an analysis by country, the cash conversion cycle presents a negative and significant coefficient for all countries except for Austria and Luxembourg which are no longer statistically significant. This means that the shorter the cash conversion cycle (CCC) in European countries, the higher the levels of profitability.

The current economic conditions have an impact on profitability, since the results indicate that profitability has fallen over the last few years.

In addition, some tests of robustness were performed. These proved to be consistent and achieved statistical significance, thus confirming the results obtained earlier.

Future research may carry out more in-depth analysis of the impact of working capital management on the profitability of firms. For example, studies can be made of a specific sector, in a context of European SMEs. In this study it was not possible to include other variables related to corporate governance due to the lack of available data, for example the gender of CEOs, the age of firms, whether a firm is audited or whether a firm is familyowned. These variables could be included in future studies.

In short, the results suggest that firms can improve their operating profitability by reducing their cash conversion cycle. 


\section{BIBLIOGRAPHY}

Abbadi, S. M and Abbadi, R. T. (2013), "The Determinants of Working Capital Requirement in Palestinian Industrial Corporations", International Journal of Economics and Finance. 5, 1. 67-75.

Abor, Joshua and Biekpe, Nicholas (2007), "Corporate governance, ownership structure and performance of SMEs in Ghana: implications for financing opportunities", Corporate Governance: The international journal of business in society, Vol. 7 Iss 3 pp. $288-300$.

Achchuthan,S., and Kajananthan, R. (2013), "Corporate Governance Practices and Working Capital Management Efficiency: Special Reference to Listed Manufacturing Companies in SriLanka”, Information and Knowledge Management, 3, 216-226.

Amarjit G., Nahum B. and Neil M. (2010), “The Relationship between Working Capital Management and Profitability: Evidence From The United States", Business and Economics Journal, 10, 1-9.

Atrill, P. (2009), Financial Management for Decision Makers, England: Pearson Education Limited.

Baltagi, B. (2008), Econometric Analysis of Panel Data, edition 4, Chichester, John Wiley \& Sons.

Baños-Caballero S. B., Teruel P. J. G. and Solano P. M. (2012b), "Working Capital requirement financing and Spanish SME performance”, Fundacion de Estudios Financieros (premios de investigacion FEF 2012).

Baños-Caballero S., García-Teruel P. J. and Martínez-Solano P. (2012a), "How does working capital management affect the profitability of Spanish SMEs?", Small Business Economics, Vol. 39(2), 517-529.

Baños-Caballero, S., García-Teruel, P. J. and Martínez-Solano, P. (2010), "Working capital management in SMEs", Accounting and Finance, Vol. 50(3), 511-527. 
Braga, R.; Nossa, V.; Marques. J. (2004), “Uma proposta para análise integrada da liquidez e rentabilidade das empresas", Revista Contabilidade e Finanças, Edição Especial.

Bruinshoofd, W.A. and Kool, C. (2002), "The determinants of corporate liquidity in the Netherlands", Maastricht University Economics Working Paper.

Deloof M. (2003), "Does working capital management affect profitability of Belgian firms?", Journal of Business Finance and Accounting, Vol.30: 573-588.

Falope, O. I. and Ajilore, O. T. (2009) "Working Capital management and corporate profitability: Evidence from Panel Data Analysis of Selected Quoted Companies in Nigeria", Research Journal of Business Management, Vol. 3(3), 73-84.

Garcia-Teruel, Pedro Juan and Martínez-Solano, Pedro, (2007), "Effects of working capital management on SME profitability”, International Journal of Managerial Finance, Vol. 3 no2.

Gill A. S. and Biger, (2013), "The impact of corporate governance on working capital management efficiency of American manufacturing firms", Managerial Finance, Vol. 39 Iss 2 pp. $116-132$.

Gill et al (2010), "The relationship between working capital management and profitability: Evidence from the United States", Business and Economics Journal, Vol.10.

Gill, A. and Mathur, N. (2011), "The impact of board size, CEO duality, and corporate liquidity on the profitability of Canadian service firms", Journal of Applied Finance and Banking, Vol. 1 No. 3, pp. 83-95.

Harford, J. (1999), “Corporate cash reserves and acquisitions, Journal of Finance”, Vol. 54, Iss. 6.

Harford, J.; Mikkelson, W. and Partch, M. (2003), "The effect of cash reserves on corporate investment and performance in industry downturns", Working Paper, Univ. of Oregon.

Hirigoyen, G. (1985). Rentabilité et solvabilité. Direction et Gestion, 3, 13-26. 
Isshaq, Z. et al (2009), "Corporate governance, disclosure and foreign share ownership in the Ghana Stock Exchange”, Managerial Auditing Journal, Vol. 24 No. 7, pp. 688-703.

J. Enqvist et al (2014), "The impact of working capital management on firm profitability in different business cycles: evidence from Finland", Research in International Business and Finance, Vol.32.

Jensen, M. (1993), "The Modern Industrial Revolution Exit and the Failure of Internal Control Systems", Journal of Finance, Vol. 48, 831-880.

Karadagli. Ece C. (2012), "The Effects of Globalization on Firm Performance in Emerging Markets: Evidence from Emerging-7 Countries”, Journal of Asian Economic and Financial Review 2(7):858-865.

Knauer, Thorsten and Wöhrmann, Arnt (2013) "Working capital management and firm profitability”, Journal of Management Control, Volume 24, Issue 1, pp 77-87.

Lazaridis e Tryfonidis, (2006); "Relationship Between Working Capital Management and Profitability of Listed Companies in the Athens Stock Exchange", Journal of Financial Management and Analysis, Vol. 19, No. 1

Lipton, Martin and Lorsch, Jay W. (1992), “A Modest Proposal for Improved Corporate Governance", The Business Lawyer, Vol. 48, No. 1.

Maddala lahiri, G.S. and Lahiri, Kajal (2009), "Introduction to Econometrics”, New York: Wiley.

Mathuva (2010), “The influence of working capital management components on corporate profitability: a survey on Kenyan lists firms”, Research Journal of Business Management, 4(1):1-11.

McLaney, E. J. (2006), Business Finance: Theory and Practice, England: Pearson Education Limited.

Mikkelson, W. and Partch, M. (2003); "Do persistent large cash reserves hinder performance?", Journal of Quantitative and Financial Analysis. 
Miringu, A. and Muoria, E. (2011), “An analysis of the effect of Corporate Governance on performance of Commercial State Corporations in Kenya", International Journal of Business and Public Management, 1, 36-41.

Mollah, S.; Farooque, A. and Karim, W. (2012), "Ownership Structure, Corporate Governance and Firm Performance: Evidence from an African Emerging Market", Studies in Economics and Finance, 29(4) 301-319.

Muller, Patrice et al, (2014), “Annual Report on European SMEs 2013/2014 - A Partial and Fragile Recovery", http://ec.europa.eu/enterprise/policies/sme/facts-figuresanalysis/performance-review/files/supporting-documents/2014/annual-report-smes2014_en.pdf acedido a 11 de Janeiro de 2015.

Myers, S.C. (1984), “The capital structure puzzle”; Journal of Finance, Vol.39, Iss.3.

Myers, S.C.; Majluf, N.S. (1984), "Corporate financing and investment decisions when firms have information that investors do not have", Journal of Financial Economics, Vol.13.

Neves, J.C. (2012), "Análise e Relato Financeiro - Uma Visão Integrada de Gestão" 5. Ed., Texto Editora.

Pell, M. J. and Wilson, N. (1996), "Working Capital and Financial Management Practices in the Small Firm Sector”, International Small Business Journal, no. 14 (2).

Petersen, M. and Rajan, R. (1997), "Trade Credit: Theories and Evidence" Review of Financial Studies", Vol. 10 (3), 661-691.

Raheman and Nasr (2007), "Working capital management and profitability - case of Pakistani firms”, International Review of Business Research Papers, Vol3, No.1.

Richards, V. and Laughlin, E. (1980), "A cash conversion cycle approach to liquidity analysis", Financial Management, Vol. 9 No. 1, pp. 32-38

Ross, S.A., R.W. Westerfield and B.D. Jordan, (2003), "Fundamentals of Corporate Finance", New York, $6^{\text {th }}$ Edn, McGraw-Hill Irwin Publications. 
Shin, H.H. and L. Soenen (1998), "Efficiency of Working Capital and Corporate Profitability", Financial Practice and Education, Vol. 8, No. 2.

Smith, K. V. (1980), "Profitability versus Liquidity Tradeoffs in Working Capital Management”, In K. V. Smith (Ed.), In Readings on the management of Working Capital, New York, St. Paul MN: West Publishing Company.

Ukaegbu (2014), “The significance of working capital management in determining firm profitability: Evidence from developing economies in Africa”, Research in International Business and Finance, Vol.31.

Van Horne, J.C. and Wachowicz, J.M., (2004), "Fundamental of Financial Management", New York, $12^{\text {th }}$ ed., Prentice Hall.

Velnampy, T. and Pratheepkanth, P. (2013), "Corporate governance and firm performance: a study of selected listed companies in Sri Lanka", European Journal of Commerce \&Management Research 2, 1-5.

Wang, Y. J. (2002), "Liquidity management, operating performance, and corporate value: evidence from Japan and Taiwan" Journal of Multinational Financial Management, Vol. 12(2), 159-169.

Yermack, D. (1996), "Higher market valuation of companies with a small board of directors." Journal of Financial Economics, 40, 185-212. 